\title{
Лес и спички
}

Реальная социально-экономическая действительность, причинно-следственные связи, на которых она зиждется, во много раз шире, сложнее наших самых смелых идей и гипотез. Но порой случается, что именно простые явления и процессы наводят на мысль о тех самых глубинных основаниях, которым прежде уделялось мало внимания. История науки и реальной практики знает много примеров научных озарений - от ньютоновского яблока до бревна сибирской лиственницы на гренландском берегу ${ }^{1}$.

Но и некоторые произведения классической литературы, как представляется, тоже могут стать прекрасной иллюстрацией этой идеи, ярко и образно отражая явления окружающего нас мира во всей сложности взаимосвязей их причин и следствий. Применительно к настоящей тематической подборке «ЭКО» кажется уместным обратиться к рассказу А.П. Чехова «Шведская спичка (уголовный рассказ)». Одному из его персонажей, как известно, удалось найти улику, которая позволила раскрыть запутанную ситуацию: «...К моим услугам шведская спичка, употребления которой еще не знают здешние крестьяне. Употребляют этакие спички только помещики, и то не все....». Спичка в данном случае стала и основой выявления причинно-следственных связей, и тем средством, при помощи которого удалось найти живым и невредимым пропавшего героя: «Дюковский чиркнул спичкой и осветил предбанник...»².

Прошедшим жарким летом 2019 г. сибирский лес горел как та самая шведская спичка, о которой нам поведали чеховские строки. Лесные пожары «осветили» многие темные углы и закоулки той действительности отечественного лесного комплекса, которые в обычной жизни не всегда можно увидеть и, тем более, понять.

\footnotetext{
1 Эта находка послужила Фритьофу Нансену толчком для обоснования гипотезы о наличии кругового течения в Северном Ледовитом океане. См.: НансенФ. «Фрам» в полярном море. М.: Государственное издательство географической литературы, 1956. Т. 1. С. $50-51$.

2 Чехов А.П. «Шведская спичка (уголовный рассказ)»// ПСС в 12 томах. М.: Государственное издательство художественной литературы. 1957. Т. 2. С. 33-36.
} 
Эта действительность далеко не исчерпывается материальными ресурсами и не может быть описана исключительно в терминах существующей системы учета и управления хозяйственной деятельности. Она, скорее, являет собой сложный комплекс тесно связанных и взаимообусловленных процессов, которые формируют и определяют место леса в социально-экономической системе нашей страны.

Современный императив понимания проблем леса имеет мало общего с примитивным «учетно-калькуляционным» подходом, применяемым для анализа и оценки лесных проектов на основе маржинальной эффективности добычи и переработки очередного кубометра древесины. Лес - это, прежде всего, здоровье населения, это возможность реализации инициатив, связанных с формированием благоприятной среды проживания как ныне живущих, так и будущих поколений россиян.

Лесные пожары лета 2019 г. с особой остротой и силой высветили недостатки господствующего утилитарного подхода к лесу. Такое отношение никак не принимает во внимание человека, его устремления и нужды, его право жить достойно самому и дать такую возможность своим детям.

В основе современного (назовем его «спичечным») подхода лежат учет только текущих издержек (как эксплуатационных, так и инвестиционных, связанных с разработкой «лесных месторождений»), невнимание к процессам воспроизводства и жизненного цикла лесных угодий, ориентация на простоту и мнимую прозрачность администрирования и управления лесными ресурсами, пренебрежение вопросами надежного информационного обеспечения функционирования лесного хозяйства, слабая вовлеченность институтов местного самоуправления в процессы подготовки и принятия решений в сфере ЛПК и т.д. Как результат - фискальная ориентация всех фрагментов чрезвычайно дисперсной и аморфной среды лесопользования. Неудивительно, что наш лес горит как «шведская спичка».

Именно поэтому авторами тематической части настоящего номера «ЭКО» рассматривается комплекс шагов и мер, направленных на изменение сформировавшейся модели лесопользования.

Так, в отношении лесных пожаров подчеркивается, что «масштаб и серьезность проблемы требуют поднятия ее решения на 
федеральный уровень, с опорой на системный, комплексный подход, что предполагает принятие принципиальных институциональных изменений» (статья Б.Н. Порфирьева). При этом анализ и оценка текущих мероприятий по охране лесов и тушению пожаров нуждаются в корректировке с позиции установки на спасение (продление) жизни людей.

Как отмечают наши авторы, нельзя не учитывать при освоении лесных ресурсов и характер жизни и деятельности населения лесных поселков. «Применение механизма приоритетных инвестпроектов свелось к выделению без аукциона больших арендных массивов крупным компаниям. В результате это привело к “выдавливанию” малого и среднего предпринимательства из лесных отношений» (статья Ю.Ш. Блама и Л.В. Машкиной).

Обоснованное и эффективное социально-ориентированное управление лесами немыслимо без «лесоустройства (в освоенных и продуктивных лесах и в лесах, переданных в аренду и постоянное пользование) и государственной инвентаризации (по всей территории страны)». Пока, к сожалению, информационное обеспечение процессов функционирования лесного хозяйства оставляет желать много лучшего (и это притом, что информационные технологии и современные методы дистанционного мониторинга открывают колоссальные возможности).

Российские (и сибирские) леса - неотъемлемая часть «легких» нашей планеты. Как отмечают наши авторы (статья А.И. Пыжева и Е.А. Ваганова), «Парижское соглашение предоставляет странам-участницам свободу в формулировании национального вклада в решение проблемы... Такой полицентрический характер принятия решений позволяет отдельным странам вести самостоятельную политику контроля за выбросами парниковых газов с учетом особенностей их политического устройства, структуры и динамики экономики».

Исторический опыт решения проблем лесопользования (многие научные школы в этой сфере имеют изначально российскую «прописку») открывает уникальные возможности интеграции и кооперации на глобальном уровне. Однако и этот опыт, и эти возможности остаются невостребованными в стране, лидирующей по экспорту малообработанной древесины. 
Лес и спички

7

Лес - неотьемлемая часть нашей идентичности и культуры, его сохранение и преумножение требуют консолидации и заинтересованного диалога всех сторон - от управленцев и специалистов до представителей местных сообществ, рядовых жителей страны. Наш общий долг - сформулировать роль и место леса в жизни России на годы вперед. Мы приглашаем заинтересованных коллег и читателей к обсуждению данных непростых проблем и вопросов. Хочется надеяться, что это можно осуществить без использования «шведских спичек» (лесных пожаров).

Главный редактор «ЭКО»

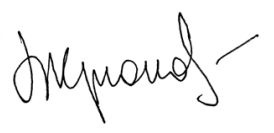

КРЮКОВ В.А. 